\title{
Leadership \& Professional Development: Empowering Educators
}

\author{
Daniel T Cronin, MD
}

Division of Hospital Medicine, Department of Internal Medicine, University of Michigan Health System, Ann Arbor, Michigan; VA Ann Arbor Healthcare System, Ann Arbor, Michigan.

"Better than a thousand days of diligent study is one day with a great teacher."

$$
\text { - Japanese proverb }
$$

My chairman of medicine in medical school was a looming, intimidating, diagnostic genius-and one of the best teachers I have ever had. As a sub-intern it seemed I learned more in one month with him than in my prior six months of medical school. After the rotation, I asked him how he became such an effective teacher. "Simple," he said, "I invest significant time and effort."

But time is limited and you have to be smart with how you invest it. Here are three pearls that are a wise investment-they will make you a better teacher.

\section{PREPARE}

Those who seem to teach effortlessly do so after substantial behind-the-scenes effort. Read on your patients before rounds. Identify key teaching points and useful literature. Get some questions ready to define knowledge gaps and create "Teaching Scripts."

Teaching Scripts are preplanned summaries of specific topics that can be used on rounds or longer talks and are "triggered" by common scenarios (eg, hypoxia). Great teaching scripts use a "hook" to engage the learner (commonly a thought-provoking question or story), two to five teaching points, and purposeful questions, mnemonics, and visual representations.

You should aim to develop at least five teaching scripts on commonly encountered topics. Eventually, you should have twenty scripts you can easily reference.

\section{USE TECHNOLOGY}

Technology significantly enhances the efficiency and impact of your teaching. For example, on rounds use your cell phone to display and teach anatomy, radiographic images, and EKGs. Use an iPad as a mobile whiteboard. Use email to collate and disseminate teaching points or send links to valuable learning resources like procedural videos. At its best, you can develop new programs and recruit team members to create resources, like I did with an online series focused on teaching to teach

Corresponding Author: Daniel T Cronin, MD; E-mail: croninda@med.umich. edu; Telephone: 518-495-1350

Received: April 8, 2019; Revised: April 18, 2019; Accepted: April 22, 2019

() 2019 Society of Hospital Medicine DOI 10.12788/jhm.3231 using graphically-enhanced TED-style talks ${ }^{1}$ and animated whiteboard videos. ${ }^{2}$

\section{LEARN FROM OTHER DISCIPLINES}

Do you easily remember the content from your medical school lectures? Likely not. But you likely remember moments from your favorite comedian or TED talk. Unlike the many PowerPoint lectures you've sat through, I'll bet you stay engaged in films and documentaries. Why the difference? In short-medical educators often don't make content engaging, readily understood, or memorable. To be most effective in teaching, learn from experts in other fields. Think how storytelling, film, theater, and graphic design contribute to learning. Don't be afraid to be different.

All of these disciplines recognize the power of storytelling to make their points more impactful and memorable. Leverage this by mixing lessons with stories to create teaching points that stick. Lessons of character and morals can be highlighted through stories of personal struggles, prior patients, or people you admire. Clinical tips can be reinforced through sharing a "clinical story" — concise retellings of high-yield patient cases with diagnosis or management tips.

These disciplines also recognize the importance of "setting the stage" to create an optimal experience. We too can learn from this by setting the stage for our learners. Build a learning environment that is positive, collaborative, and fun by being open, curious, and enthusiastic. Treat your team to coffee rounds or lunch and get to know each learner as you walk between patients. As Teddy Roosevelt said, "people don't care how much you know, until they know how much you care."

My chairman taught me that exceptional teaching is not a talent of the gifted, it is a skill of the diligent. If you invest in your teaching, you can make a tremendous impact in the lives of your learners. Are you ready to be empowered?

\section{Acknowledgments}

The author wishes to thank Rana Kabeer and Sally Salari for their assistance in storyboarding, graphic design, and video editing of the MENTOR Video Series. Disclosures: Dr. Cronin has nothing to disclose.

\section{References}

1. Kabeer R, Salari S, Cronin D. MENTOR Video Series: The Golden Secret. [Video]. 2019. Available at: http://mentorseries.org/FeedbackGS.

2. Kabeer R, Salari S, Cronin D. MENTOR Video Series: Effective Feedback Summary - The 5Ps. [Video]. 2019. Available at: http://mentorseries.org/Feedback5Ps. 